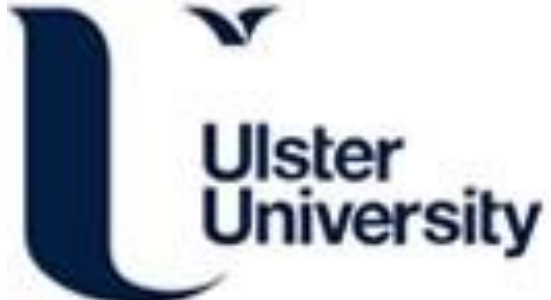

“Influence of the Global Environment on Capital Flows in the London Office Market."

McCord, M., \& Fadeyi, O. (Accepted/In press). "Influence of the Global Environment on Capital Flows in the London Office Market.". Journal of European Real Estate Research. https://doi.org/10.1108/JERER-05-20210029

Link to publication record in Ulster University Research Portal

Published in:

Journal of European Real Estate Research

Publication Status:

Accepted/In press: 07/12/2021

DOI:

10.1108/JERER-05-2021-0029

\section{Document Version}

Author Accepted version

\section{General rights}

Copyright for the publications made accessible via Ulster University's Research Portal is retained by the author(s) and / or other copyright owners and it is a condition of accessing these publications that users recognise and abide by the legal requirements associated with these rights.

\section{Take down policy}

The Research Portal is Ulster University's institutional repository that provides access to Ulster's research outputs. Every effort has been made to ensure that content in the Research Portal does not infringe any person's rights, or applicable UK laws. If you discover content in the Research Portal that you believe breaches copyright or violates any law, please contact pure-support@ulster.ac.uk. 


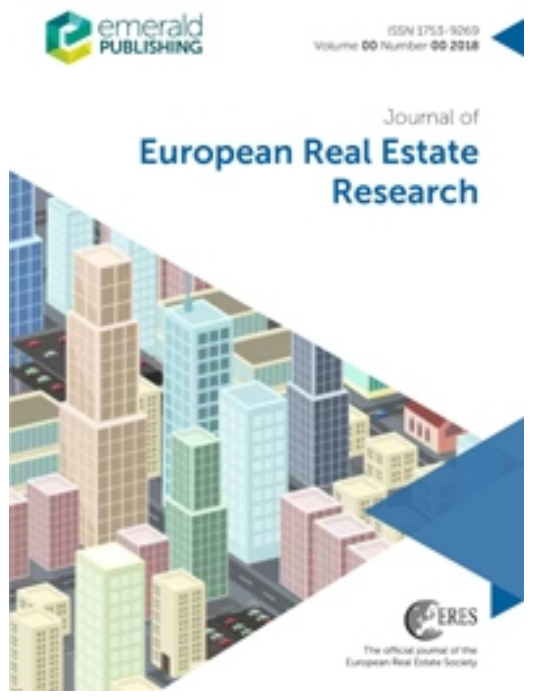

\section{Influence of the Global Environment on Capital Flows in the London Office Market.}

\begin{tabular}{|r|l|}
\hline Journal: & Journal of European Real Estate Research \\
\hline Manuscript ID & JERER-05-2021-0029.R2 \\
\hline Manuscript Type: & Research Paper \\
\hline Keywords: & $\begin{array}{l}\text { Office market, Global cities, International investment, Auto-regressive } \\
\text { Distributed Lag Approach (ARDL), Cointegration. }\end{array}$ \\
\hline \multicolumn{2}{|l}{} \\
\hline
\end{tabular}

\section{SCHOLARONE ${ }^{\text {m }}$ \\ Manuscripts}




\title{
Influence of the Global Environment on Capital Flows in the London Office Market.
}

\begin{abstract}
Purpose: The London office market is a major destination of international real estate capital and arguably the epicentre of international real estate investment over the last decade. However, the increase in global uncertainties in recent years due to socio-economic and political trends highlights the need for more insights on the behaviour of international real estate capital flows. The study evaluates the influence of the global and domestic environment on international real estate investment activities within the London office market over the period 2007 to 2017 .
\end{abstract}

Study design/methodology/approach: This study adopts an Auto-Regressive Distributed Lag (ARDL) approach using the Real Capital Analytics (RCA) international real estate investment data. The RCA data analyses quarterly cross-border investment transaction within the central London office market for the period 2007 to 2017.

Findings: The study provides insights on the critical differences in the influence of the domestic and global environment on cross-border investment activities in the London office market, specifically highlighting the significance of the influence of the global environment in the long-run. In the short-run, the influence of factors reflective of both the domestic and international environment are important indicating that international capital flows into the London office market is contextualised by the interaction of different factors.

Originality/value: The authors provide a holistic study of the influence of both the domestic and international environment on cross-border investment activities in the London office market, providing more insights on the behaviour of global real estate capital flows.

Keywords - Office market, Global cities, International investment, Auto-regressive Distributed Lag Approach (ARDL), Cointegration.

\section{Introduction}

In a rapidly changing global political and economic landscape, the commercial real estate (CRE) sector is not immune to the impact of the increasing uncertainty in relation to investment volumes, particularly cross-border investment flows. As an integral component of the global 
economy, the office market is a major destination of capital flows and susceptible to the impact of shocks in international financial markets on occupier, investment and debt markets (Lizieri and Pain, 2014). Conventionally, investment into the real estate office sector is largely concentrated in prime locations within major global cities and notably in London (Lizieri and Pain, 2014; Stevenson et al., 2014; Zhu and Lizieri, 2020). Indeed, between 2007 and 2016, the London office market attracted around $11.5 \%$ of global office investment in this period (Zhu and Lizieri, 2018). In addition, the evaluation of the inter-relationships between CBD office markets further highlights the pre-eminence of the London office market (Fadeyi et al., 2020, Zhu and Lizieri, 2020). Accordingly, Zhu and Lizieri (2020) emphasise the supremacy of the London office market as the global real estate investment epicentre due to the intensity of its ownership linkages and shock transmission to other cities.

Between 2007 and 2017, the London office market attracted around \$183.4B cross-border investments. In sharp contrast major cities such as New York and Tokyo attracted significantly lower cross-border investment volumes of around $\$ 80.2 \mathrm{~B}$ and $\$ 39.2 \mathrm{~B}$ (respectively) in the same period (Zhu and Lizieri, 2020). Furthermore, as highlighted by Fadeyi (2020), developers, investment managers and equity funds were the key players in this market between 2007 and 2017. In terms of foreign capital flows, investments originating from the US, Germany and Hong Kong dominated the market in this period with international pathways for real estate capital flows such as US- UK, Germany - UK and US-US prominent and accounting for investment volume of circa $\$ 14.8 \mathrm{~B}, \$ 9.32 \mathrm{~B}$ and $\$ 8.35 \mathrm{~B}$ respectively.

The London office market has continued to attract significant investment flows over the last two decades despite relatively modest market performance (Fadeyi, 2019), reduction in the potential diversification benefits (Lizieri and Pain, 2014; Srivatsa and Lee, 2012; Stevenson et al., 2014; McAllister and Nanda, 2015) and the increasing significance of the emerging markets (Burrell, 2015; Haran et al., 2016). Although, in the aftermath of the 2007 Global Financial Crisis, the level of cross-border capital flow into the international office market reduced significantly, the London office market experienced sizable increases in cross-border investment activity in the downturn, with the percentage of deals between non-UK parties increasing considerably (Fadeyi, 2020). Notwithstanding the shift in the origin of cross-border investments in the downturn by both country of origin and investor type, the London market continued to attract stable volumes of international capital flows between 2007 and 2009. These continued flows of international capital, was arguably reflective and symptomatic of the 'flight 
to prime' which in turn enhanced the London office market liquidity particularly during the crisis period. Similarly, in the aftermath of the 2016 Brexit vote, and ensuing political uncertainty, whilst the general investment level into the UK commercial property market initially dropped, the significance of cross-border investments into the London office market relative to the domestic investments - increased as the value of sterling against other major currencies depreciated. Furthermore, during the COVID-19 pandemic and lockdown, RCA (2021) report on most active commercial property markets in 2020, indicates that the London market attracted the largest share of cross-border investment in 2020.

Despite the continued dominance of the London market as a major destination for cross-border investment, other cities such as emerging global cities are becoming more prominent and key actors for investors (Burrell, 2015). As highlighted by Haran et al. (2016), investor focus is shifting to other locations such as the emerging markets in search of diversification and investment opportunities. This increasing significance of real estate capital flows into emerging markets has rekindled interest on the drivers of real estate capital flows and the performance of real estate markets in the established global cities particularly the London office market (Burrell, 2015). Similarly, the increase in global uncertainties due to socio-economic and political trends, for instance BREXIT, global conflicts, de-globalisation agendas and the impact of the recent COVID-19 pandemic highlight the need for more insights on the behaviour of international real estate capital flows.

Interestingly, as Akinci et al. (2020) illustrate, the COVID-19 outbreak triggered a collapse in capital flows more severe in size and speed than preceding crises, culminating in sudden stop episodes of dollar funding from emerging market economies (EMEs). This as Nickol and Stoppok (2020) discuss, witnessed cumulative outflows by foreign investors of almost $\$ 100$ billion within the first three months of the pandemic and approximately $\$ 20$ billion in emerging market portfolio bonds, constituting a historically unprecedented "flight to safety." Corsetti and Marin (2020) also highlight that the Volatility Index (VIX), a measure for stock market volatility and global risk aversion, and one of the main co-moving factors of international capital flows (see: Broner et al., 2013) reached its highest level since the GFC leading to large foreign exchange (FX) moves and exchange rates against the dollar, manifesting in an inverted US yield curve. This showed the US dollar initially losing value against the Euro, Japanese yen and remain in parity with the sterling before rebounding and strengthening markedly against all currencies, driving potential changes in investment patterns. Equally, Beirne et al. (2021) 
examining asset markets and capital flows, show that emerging markets have been more heavily affected than advanced economies and have experienced the sharpest impacts on stock, bond and exchange rates due to COVID-19., with quantitative easing and fiscal stimulus packages reducing uncertainty within advanced economies and between financial centres' stock market volatility and capital flows.

Real estate markets in advanced economies and financial centres' have remained relatively resilient due to the economic stimulus packages and also due to the shifting demand patterns which were already crystallising over the past few years due to changing transitions towards online retail and shifting working patterns which were already altering demand for office space (flexi-office space), albeit this has arguably been accelerated by the COVID-19 epidemic. As the 'new normal' and shifts in occupier demand feeds into capital flows and wider investment patterns, demand is more likely to hold up in key financial centres, thus the role of this paper remains current in terms of understanding the dynamics of investor patterns and flows in a post-pandemic setting.

Therefore this paper, focusing on the London office market and employing an Auto-Regressive Distributed Lag (ARDL) approach, provides an evaluation of the influence of the domestic and international environment in order to provide nuanced insights on the behaviour of cross-border real estate capital flows. This is realised through the assessment of the significance of domestic and international factors on international real estate capital flows using two models specific to the London market in order to explore those issues that are influential in explaining crossborder real estate capital flow into the London office market.

\section{Literature Review}

The London office market has uniquely been a top destination of global cross-border capital over the last two decades and possesses crucial socio-economic and institutional attributes that enhance its competitiveness in attracting capital flows. Previous studies on real estate capital flows highlight the influence of factors such as overall economic growth and conditions, institutional and legal barriers, real estate market performance, liquidity and transparency, the exchange rate, interest rates, market size, investment location, information cost on real estate investment activities and capital flows (McGreal et al. ,2001; Chin et al., 2006; Pi-Ying Lai and Fischer, 2007; Lieser and Groh, 2014; Fuerst et al.,2015; McAllister and Nanda, 2016; 
Salem and Baum, 2016; Devaney et al., 2017a; Devaney et al., 2017b; Poon, 2017; Gupta et al., 2020).

Indeed, extant literature on factors underpinning capital market flows generally highlights the impact of either the domestic (pull) or global (push) factors on different types and waves of international capital flows. Research conducted by Alfaro et al. (2007) focused on the domestic factors driving international capital inflows (specifically FDI and portfolio equity inflows) for 47 countries (including both developed and developing countries) between 1970 and 2000. Evaluating the significance of receiving countries' (pull factor) characteristics and the significance of national institutional and structural factors in driving foreign capital flows, it established that national factors such as institutional quality, human capital endowment and distance are important determinants of capital inflow. In their analysis, Alfaro et al. (2007) articulate the positive impact of British legal origin on capital inflows as well as the impact of policy on capital inflow levels and volatility. In addition to the impact of national factors, Fostel and Kaminsky (2008) examined the role of external factors such as yield spread, US real interest rates, and world issuance to capture global liquidity. Employing gross issuance data in the bond, equity and syndicated-loan markets between 1980 and 2005, for capturing capital inflows (especially when global liquidity is low), the authors found that domestic factors played a dominant and important role in driving capital flows during the early 1990s, while external factors (global liquidity) became dominant factors - specifically after 2002.

Reinhart and Reinhart (2009) also examined the causes and consequences of large capital inflows (bonanzas or surge in capital inflows) to both advanced and emerging economies. Using annual data for 181 economies between 1980 and 2007, measuring capital flows based on the current account balance, the study links surges in capital inflows to global factors such as growth in advanced economies, international interest rates and global commodity pricing. Their findings showed that the various episodes of capital inflow surges - which they contend arguably became more frequent due to relaxation of capital controls - tend to be temporary (lasting between 2 and 4 years). Indeed, their analysis revealed negative consequences such as increased risk of economic crisis (debt default, banking, inflation and currency crash) in emerging economies and economic vulnerability in developing countries. The authors suggest that this is due to fiscal policies and attempts to restrict exchange rate appreciation, and also due to capital inflow surges being associated with more volatile macroeconomic outcomes, in terms of GDP growth, inflation, and the external accounts. 
In a similar study, Forbes and Warnock (2012) investigated the factors driving extreme international capital flows within 58 countries between 1985 and 2009. In order to encapsulate the complete dynamics and causes of extreme capital flow movements, the authors differentiate between foreign and domestic investors' activities by focusing on gross capital inflows and outflows instead of the net capital flows which they contend do not reflect the increase in gross capital flow size and volatility. Their study finds that change in global risk is the primary factor associated with all the extreme capital flow episodes, while contagion is only associated with retrenchment and stop episodes. Interestingly, they also indicate that domestic macroeconomic factors are generally less significant as well as changes in global liquidity or interest rates in advanced economies (particularly significance to surges in capital flows).

Taking into consideration the significance of both global and country specific factors to global capital flows, Shirota (2015) scrutinised the relative significance of the contribution of push (global and regional common) factors and pull (country-specific) factors to the volatility of international banking flows across 70 countries. The study demonstrates that the contribution of both factors varies across countries, inferring that push factors explains between 40-50 percent of volatility in overall international banking flows, and that the significance of the push factor contribution has increased since 2000. Similarly, Sarno et al. (2016) evaluated the relative importance of the contribution of push (global and asset specific) factors and pull (country-specific) factors to the variation of bond and equity flows from the US to 55 other countries. The study revealed that the common push factor prevails over the country-specific factor by explaining more than $80 \%$ of the variation in international portfolio flows, thereby indicating that the main determinants of global portfolio flows are the financial globalization forces.

Moving on from studies focusing on the factors driving global capital flows, Bluedorn et al. (2013) investigated the effect of financial globalisation on the behaviour of capital flows across 147 countries between 1980-2011. Pertinently, it the appraised the evolving nature of capital flows across different countries, from a long-term perspective, by analysing a dataset of both gross and net capital flows for variations in trends, composition, volatility, persistence and sensitivity to the global environment. The findings showed that there is no significant difference in the volatility of capital flows over time and between the various economies, indicating that the apparent increase in capital flow volatility is largely due to the increasing volume over time. However, the results did uncover that FDI flows are the least volatile and 
most predictable. In terms of the behaviour of the capital flows in relation to the global environment, the findings further illustrated that net global capital flows increase when global economic conditions are benign. More specifically, Bluedorn et al. (2013) highlighted that net international capital flows into emerging economies increases when both global interest rates (interest rate in advance economies) and risk aversion are low, implying that investors tend to invest more in advanced economies when they have low risk appetite.

In the context of the real estate investment sector, Lieser and Groh (2014) investigated the impact of various socio-economic, demographic and institutional characteristics on real estate investment activities. Using panel real estate investment data series for 47 countries between 2000 to 2009, they found a positive impact of economic growth, demographics and urbanization on real estate investment activities, whilst revealing institutional and legal barriers (such as lack of transparency within the legal framework, administrative burdens of doing real estate business, socio-cultural challenges, and political instabilities) to exhibit negative impacts. Building on the Lieser and Groh (2014) framework, Fuerst et al. (2015) used a panel of international real estate capital flows data to evaluate the determinants of cross-border capital flows into national real estate markets. The study explored the significance of institutional and legal barriers on capital flows (both domestic and foreign), revealing that these barriers do not significantly affect capital inflows. However, Fuerst et al. (2015) in their study do highlight the return chasing behaviour of foreign investors and the significance of real estate market liquidity as major determinants of real estate capital flows, which they suggest demonstrate the importance of real estate market transparency (based on JLL Transparency Index) in attracting capital flows. Equally, McAllister and Nanda (2016) investigated the scale and determinants of foreign investment flows between real estate markets at national levels. Using RCA real estate investment flow data for over 100 countries between 2007 and 2012, and employing a gravity model, the authors observed the positive impact of market size and information cost as well as the negative impact of distance between foreign investors and investment location on foreign real estate investment flows.

Similarly, other studies focusing on specific geographical locations highlight the significance of various domestic factors. The studies of Chin et al. (2006) and Pi-Ying Lai and Fischer (2007) focusing on Asia, indicate the importance of domestic factors such as political stability and legal regulations, national economy, sound financial and economic structures. Salem and Baum (2016) also highlight the importance of political stability, among other domestic factors, 
to international real estate investment flows in the in the Middle Eastern and northern African countries. Similarly, Devaney et al. (2017a) examining a total of 38 European and Asian Pacific countries, highlighted the significance of domestic factors namely: the size and wealth of a country, the specific country risk and property rights, as well as the performance of the real estate markets. Gupta et al. (2020) evaluation of the determinant of foreign and domestic nonlisted real estate fund flows in India, indicate the influence of the real GDP and asset performance on domestic flows. While the foreign flows are driven by the exchange rate, asset performance and the domestic flows.

In term of Eastern European countries, earlier research undertaken by McGreal et al. (2001) revealed the significance of market transparency, overall economic conditions, corruption and bureaucracy to foreign real estate investment activity in this region. Devaney et al. (2017b) study on the US metropolitan office markets project the positive impact of occupancy rate, economic growth rate and market size, as well as the negative impact of capital market risk and transaction tax on the turnover rates. Poon (2017) analysis of the key factors affecting foreign real estate investment in London residential market, indicate the positive impact of GDP, wages, house and land price, and the negative impact of interest rates on foreign real estate investment.

As suggested by the evaluation of studies on factors underpinning capital market flows, international capital flows are not only influenced by the domestic (pull) factors but also by the global (push) factors. Accordingly, this paper examines the influence of both the domestic and international environment on cross-border real estate capital flows into London office market and exploring the research question as to whether international real estate investment in the London office market is influenced by the underpinning market dynamics or international factors?

\section{Data}

To evaluate the influence of the domestic and international environment on cross-border real estate capital flows into the London office market, this research uses the Real Capital Analytics (RCA) ${ }^{[1]}$ CBD office quarterly property transactions over the period 2007 to 2017 . RCA tracks the sale of income-producing property (including development sites) and portfolios transacted at a minimum of $\$ 10$ million in 172 countries in the Americas, Europe, Middle East and Africa and Asia-Pacific. The database provides deal information behind the $\$ 18$ trillion property 
transactions capturing aspects such as the origin and destination of the investment flows, investors profile and property types for measuring global real estate investments trends. RCA is widely recognized as the leading specialist in commercial real estate investment transaction data and is widely used by industry experts and in academic research.

This paper analyses the gross quarterly cross-border investment transactions on office property in central London for the period 2007 to 2017. For the purpose of this study, transactions for which either (or both) the selling and purchasing parties are non-UK based are classified as cross-border investment flows as opposed to domestic UK investment activity ${ }^{1}$. In total, 1,585 transactions with an investment sum of circa $\$ 183.4 \mathrm{~B}$ were captured.

Other variables considered in this analysis draw upon the existing literature base and include domestic factors namely: long term interest rates, real effective exchange rates, total returns, UK GDP, stock market capitalization, equivalent yield impact and gross rental yield. In addition to these domestic variables, appropriate variables for the global environment such as VIX index measure of global risk, world long-run interest rates and money supply to control for global (ill)liquidity are considered in the extended model specification (Table I).

\section{Table I}

Other variables such as the stock market capitalization for US and Japan, as well as gross rental yield spreads between London, New York and the Tokyo office markets are included to examine and control for the influence of the other two major financial centres (cities) on crossborder real estate capital flow into the London office market (Table II). These variables are included to provide a more robust analysis of the influence of the general international environment on international real estate flows to London office market and simultaneously to control for investor rationale as to select London (or not) as opposed to these key cities (centres) $)^{2}$.

\section{Table II}

\section{Methodology}

\footnotetext{
${ }^{1}$ This includes international to domestic, domestic to international and international to international transactions. ${ }^{2}$ Appendix 1 shows the summary statistics of the variables.
} 
This paper applies two $\mathrm{ARDL}^{3}$ models to evaluate the long-run and short-run influence of the domestic and international environment on cross-border real estate capital flows into the London office market. The justification for selecting the ARDL model as opposed to other cointegration techniques is firstly, unlike traditional co-integration methodologies, the ARDL cointegration test is applicable when the variables are integrated of different orders, i.e. $I(0)$ or I(1). Secondly, as illustrated in the work of Rapach and Struss (2009), the ARDL approach tends to outperform benchmark AR models. Equally, Rapach and Struss (2007) tested an ARDL framework for forecasting purposes and revealed the importance of combining different lag structures for increasing forecast accuracy. Furthermore, this ARDL methodology, as contended by Pesaran et al. (2001), is more efficient and robust in terms of (un)biased estimation as a consequence of small sample size when compared with other widely established procedures (Johansen, 1991; Harris and Sollis, 2003; Shrestha and Bhatta, 2018). Existing studies (Lee, 2013; Worthington and Higgs, 2013; Liow, 2014; Liow and Schindler, 2017; Darku, 2019) have employed this approach and in the real estate context, Lee (2013) illustrated well the merits of the ARDL approach.

To illustrate the ARDL model, the following simple model can be considered:

$$
\mathrm{y}_{\mathrm{t}}=\mathrm{C}_{\mathrm{t}}+\beta \mathrm{x}_{\mathrm{t}}+\delta \mathrm{z}_{\mathrm{t}}+\varepsilon_{t}
$$

Where $\varepsilon_{\mathrm{t}}$ is the stochastic white noise at time $t$

The error correction version of the ARDL model is expressed as follows:

$$
\begin{aligned}
& \mathrm{D}\left(\mathrm{y}_{\mathrm{t}}\right)=\alpha_{0}+b_{1} \mathrm{y}_{\mathrm{t}-1}+b_{2} \mathrm{x}_{t-1}+b_{3} \mathrm{z}_{t-1}+\sum_{i=1}^{p} \quad \alpha 1 \mathrm{i} D\left(Y_{t-i}\right)+\sum_{i=1}^{p} \quad \alpha 2 \mathrm{i} D\left(x_{t-i}\right)+\sum_{i=1}^{p} \alpha 3 \mathrm{i} D\left(Z_{t-i}\right) \\
& +\varepsilon_{t}
\end{aligned}
$$

Where $\mathrm{D}$ is the first difference and $\varepsilon_{t}$ is the error term.

The left-hand side in the equation (2) represents the dependent variable. The first to the third expressions $\left(b_{1}-b_{3}\right)$ on the right-hand side indicate the long-run relationship between the variables. The remaining expressions with the summation sign represent the short-run dynamics of the model.

\footnotetext{
${ }^{3}$ The pre-modelling analysis of the study reveals that the variables are of mixed order of integration, therefore the ARDL approach is the most appropriate (Pesaran et al. 2001; Shrestha and Bhatta, 2018)
} 
The first procedure in the ARDL bounds approach is to estimate the equation and then test the hypothesis (F test) of no cointegration among the variables, denoted as:

$$
\mathrm{H}_{0}: b_{1}=b_{2}=b_{3}=0
$$

Against the existence of cointegration among the variables, denoted as:

$$
\mathrm{H}_{1}: b_{1} \neq b_{2} \neq b_{3} \neq 0
$$

To establish both the long- and short-run relationships, the following four steps are applied, namely: (a) Unit root test to ensure none of the series are $I(2)$, (b) ARDL bounds test approach for testing cointegration, (c) ECM to estimate long and short-run dynamics and diagnostics tests and (d) Wald exogeneity test and diagnostics tests.

Although the unit root test is not a prerequisite for ARDL, it is important to ensure that the variables are not $I(2)$, to avoid spurious results. Therefore, the initial model examines the level (order) of integration and stationarity to determine the long-run relationship hypothesis. The ADF test is applied to all the variables considered, as shown in Table III, the results indicate different levels of integration.

\section{Table III}

Given the difference in units of measurement and scale, and the significant variations in the method of reporting variables such as the UK GDP, total cross-border capital inflows, the REER and the UK stock market capitalization are transformed into their natural logarithms. The MSCI total return variables are valuation-based property indices and comprise autocorrelation (Brown and Matysiak, 2000) as current valuation $\left(\mathrm{V}_{\mathrm{t}}\right)$ is a weighted function of the present market value $\left(\mathrm{V}_{\mathrm{t}^{*}}\right)$ and the immediate past valuation $\left(\mathrm{V}_{\mathrm{t}-1}\right)$. That is:

$$
\mathrm{V}_{\mathrm{t}}=\mathrm{aV}_{\mathrm{t}^{*}}+(1-\mathrm{a}) \mathrm{Vt}_{-1}
$$

(Equation 3)

To compare the total return variables with the wider capital market data, the returns are subsequently desmoothed (unsmoothed) by assigning a de-smoothing parameter weighting (a and $(1-a))^{4}$, to reflect greater volatility which is comparable with capital market data in line

\footnotetext{
${ }^{4}$ The desmoothing parameter of 0.5 was applied to the MSCI data in line with extant studies.
} 
with extant studies such as Giliberto (1992), Hartzell and Shulman (1988), Newell and Lin Lee (2011) and Haran et al. (2015).

\section{Empirical results}

The analysis is performed on two distinct models developed for analysing capital flows into the London Office market. The first is domestically driven (London domestic model (1)) which includes the evaluation of the influence of the domestic environment on real estate investment capital flows into the London office market. The second (London international capital flow domestic model (2)) extends the analysis by incorporating additional variables for the global environment such as VIX index measure of global risk, world long-run interest rates, money supply to control for global (ill)liquidity, stock market capitalization for US and Japan, as well as gross rental yield spreads between London, New York and the Tokyo office markets.

The ARDL specification for models (1) and (2) are therefore expressed as follows:

$\mathrm{D}\left(\right.$ LLONFLOW $\left._{\mathrm{t}}\right)=\alpha_{0}+b_{1}$ LLONFLOW $_{\mathrm{t}-1}+b_{2}$ GRRYIELDLON $_{t-1}+b_{3}$ LUKGDP $_{t-1}+$ $b_{4}$ LUKMCAP $_{t-1}+b_{5}$ LUKREER $_{t-1}+b_{6}$ TOTAL RETURN DES $_{t-1}+b_{7}$ EQUIVYIELD IMPACT $_{t-1}$ $+b_{8}$ UK LTIR $_{t-1}+\sum_{i=1}^{p} \alpha 1 i \mathrm{D}\left(\right.$ LLONFLOW $\left._{\mathrm{t}-1}\right)+\sum_{i=1}^{q} \alpha 2 i \mathrm{D}\left(\right.$ GRRYIELDLON $\left._{t-1}\right)+$ $\sum_{i=1}^{q} \alpha 3 i \mathrm{D}\left(\right.$ LUKGDP $\left._{t-l}\right)+\sum_{i=1}^{p} \alpha 4 i \mathrm{D}\left(\right.$ LUKMCAP $\left._{t-l}\right)+\sum_{i=1}^{q} \alpha 5 i$ D LUKREER $\left._{t-l}\right)+$ $\sum_{i=1}^{q} \alpha 6 i$ D(TOTAL RETURN DES $\left.{ }_{t-1}\right)+\sum_{i=1}^{p} \alpha 7 i$ D(EQUIVYIELD IMPACT IMPl- $)+$ $\sum_{i=1}^{q} \alpha 8 i \mathrm{D}\left(\mathrm{UK} \mathrm{LTIR}_{t-1}\right)+\varepsilon_{\mathrm{t}}$

(Equation 4)

$\mathrm{D}\left(\right.$ LLONFLOW $\left._{\mathrm{t}}\right)=a_{0}+b_{1}$ LLONFLOW $_{\mathrm{t}-1}+b_{2}$ GRRYIELDLON $_{t-1}+b_{3}$ LUKGDP $_{t-1}+$ $b_{4}$ LUKMCAP $_{t-1}+b_{5}$ LUKREER $_{t-1}+b_{6}$ TOTAL RETURN DES $_{t-1}+b_{7}$ EQUIVYIELD IMPACT $_{t-1}$ $+b_{8}$ WLTIR $_{t-1}+b_{9}$ LVIX $_{t-1}+b_{10}$ LGLDITY $_{t-1}+b_{11}$ LUSMKTCAP $_{t-1}+b_{12}$ LJPMKTCAP $_{t-1}$ $+b_{13}$ TOKSPREAD $_{t-1}+b_{14}$ NYSPREAD $_{t-l}+\sum_{i=1}^{p} \alpha 1 i$ D(LLONFLOW t-1 $)+\sum_{i=1}^{q} \alpha 2 i$ $\mathrm{D}\left(\mathrm{GRRYIELDLON}_{t-l}\right)+\sum_{i=1}^{q} \alpha 3 i \mathrm{D}\left(\operatorname{LUKGDP}_{t-1}\right)+\sum_{i=1}^{p} \alpha 4 i \mathrm{D}\left(\operatorname{LUKMCAP}_{t-l}\right)+\sum_{i=1}^{q} \alpha 5 i$ $\mathrm{D}_{\left(\text {LUKREER }_{t-1}\right)+\sum_{i=1}^{q} \alpha 6 i}$ D(TOTAL RETURN DES $\left.{ }_{t-l}\right)+\sum_{i=1}^{p} \alpha 7 i$ D(EQUIVYIELD $\left.\operatorname{IMPACT}_{t-l}\right)+\sum_{i=1}^{q} \alpha 8 i \mathrm{D}\left(\mathrm{WLTIR}_{t-l}\right)+\sum_{i=1}^{q} \alpha 9 i \mathrm{D}\left(\operatorname{LVIX}_{t-l}\right)+\sum_{i=1}^{q} \alpha 10 i \mathrm{D}\left(\right.$ LGLDITY $_{t-}$ $\left.{ }_{l}\right)+\sum_{i=1}^{q} \alpha 11 i \mathrm{D}\left(\right.$ LUSMKTCAP $\left._{t-1}\right)+\sum_{i=1}^{q} \alpha 12 i \mathrm{D}\left(\operatorname{LJPMKTCAP}_{t-1}\right)+\sum_{i=1}^{q} \alpha 13 i$ $\mathrm{D}\left(\mathrm{TOKSPREAD}_{t-1}\right)+\sum_{i=1}^{q} \alpha 14 i \mathrm{D}\left(\mathrm{NYSPREAD}_{t-1}\right)+\varepsilon_{\mathrm{t}}$ 
Where $\mathrm{D}$ is the first difference, expressions $\left(b_{l}-b_{8}\right)$ the long-run relationships, a1i-a8i and a1ia14i the short-run dynamics and $\varepsilon_{\mathrm{t}}$ is the error term.

Table IV presents the results of the ARDL bounds tests. The calculated Wald $F$-statistic for the two model equations are statistically significant $(p<.05)$ and surpasses the upper bound critical value threshold indicating the presence of long-run cointegration ${ }^{[2]}$. In light of the presence of a cointegrating equation ${ }^{[3]}$ in model (1), the findings indicate that all variables in the model are not statistically significant $(p>.05)$ with the exception of the UK stock market capitalization coefficient. This suggests that the UK stock market capitalization comprises a significant and positive impact on London international flows with a $1 \%$ increase in the stock market capitalization leading to an increase of about $1.5 \%$ in the total cross-border investment flows to the London CBD office market. This highlights the significance of the level of domestic investors' confidence in facilitating international investment activities in the London office market in the long-run.

\section{Table IV}

However, in model (2), the UK gross rental yield display positive impact on the capital flows into London at the $10 \%$ level. The real effective exchange rate coefficient (-4.373) is the only domestic financial market performance factor with a significant long-run relationship at the $5 \%$ level. The inference being that a $1 \%$ appreciation of the pound sterling will lead to a $4.4 \%$ decrease in the total cross-border investment flows to the London CBD office market (Table 8). This is in line with the cross-border investment trend illustrated in Fadeyi et al. (2020), which showed increases in cross-border capital flows into the London office sector in the aftermath of the 2007 GFC and even the 2016 Brexit vote as the pound sterling depreciated sizeably in these periods.

In terms of the more international factors, global liquidity (control), the US stock market capitalization, Tokyo gross rental yield spread, and the world long-run interest rates are all statistically significant at the 5\% level. Interestingly, the reported coefficient estimate of the global liquidity (-4.963) suggests that a 1\% decrease in the global liquidity will lead to around $4.96 \%$ increase in the total cross-border investment flows to the London CBD office market. This finding supports the argument that in periods of global illiquidity London, due to its perceived 'safe haven' characteristics, can in fact increase its share of cross border investment flows. Likewise, the estimated coefficient of the US stock market capitalization variable 
(LUSMKTCAP) indicates that a $1 \%$ increase in the US stock market capitalization leads to circa $1.75 \%$ increase in the capital flows into the office sector in London. This finding links the level of investors' confidence in the US to real estate investment in London, indicating an increase in real estate investment in London offices as the confidence of the US investors increases (probably in search of diversification benefits).

Alternatively, both the Tokyo gross rental yield spread (TOKSPREAD) and the world longterm interest rates variables (WLTIR) indicate a negative long-run relationship with the London cross-border capital flow as expected. The estimated coefficient of Tokyo gross rental yield spread variable $(-1.181)$, indicating that a $1 \%$ decrease in the Tokyo gross rental yield spread will result in a circa $1.8 \%$ increase in London cross-border capital flows. This implies that changes in the performance of the Tokyo office market influences cross-border investments in the London market suggesting that when yield advantages in Tokyo are eroded investors are seemingly showing a preference for the London Office market. Equally, the world long-term interest rates variable (WLTIR) estimated coefficient of -0.346 , suggests that a $1 \%$ decrease in world long-term interest rates will lead to around $0.35 \%$ increase in capital flows into London offices. Seemingly, changes in the performance of the bond market impacts the level of cross-border investment in London offices in the long-run.

Whilst the ARDL models revealed numerous cointegrating equations, a number of the longrun parameters did not show statistical significance. Therefore, the Error correction model (ECM) associated with the long-run estimates is developed to test for the speed of adjustment and how the variables converge towards equilibrium in the long-run. The ARDL version of the ECM for models (1) and (2) can be expressed in Equation 6 and 7. The unrestricted error correction version of the ARDL models are as follows:

$$
\begin{aligned}
& \mathrm{D}\left(\text { LLONFLOW }_{\mathrm{t}}\right)=\alpha_{0}+\sum_{i=1}^{p} \alpha 1 \mathrm{D}\left(\text { LLONFLOW }_{\mathrm{t}-1}\right)+\sum_{i=1}^{q} \alpha 2 \mathrm{D}\left(\text { GRRYIELDLON }_{t-1}\right)+ \\
& \left.\sum_{i=1}^{q} \alpha 3 \mathrm{D}\left(\text { LUKGDP }_{t-l}\right)+\sum_{i=1}^{p} \alpha 4 \mathrm{D}\left(\text { LUKMCAP }_{t-l}\right)+\sum_{i=1}^{q} \alpha 5 \mathrm{D}_{\left(\text {LUKREER }_{t-l}\right)}\right)+ \\
& \left.\left.\sum_{i=1}^{q} \alpha 6 \text { D(TOTAL RETURN DES } \text { T.- }\right)+\sum_{i=1}^{p} \alpha 7 \text { D(EQUIVYIELD IMPACT } \text { IIt-l }\right)+\sum_{i=1}^{q} \alpha 8 \\
& \mathrm{D}\left(\mathrm{UK} \mathrm{LTIR}_{t-1}\right)+\mu \mathrm{ECT}_{t-1}+\varepsilon_{\mathrm{t}}
\end{aligned}
$$




\section{Table V}

The coefficient estimates of the error correction term (in model (1)) displays a value of -0.95 revealing that $95 \%$ of the disequilibrium observed in the current period is corrected in the following quarter. This finding implies that the interaction of these explanatory variables (in the long-run) through the error correction term, influence the level of cross-border capital flows within the London CBD office market. In the short-run, only the UK long-term interest rates and the real effective exchange rates are significant at the 5\% level. This infers that the level of cross-border capital flows towards the London CBD office market is negatively and significantly related to a one-quarter lag of the UK long-term interest rates. Indeed, the estimated UK long-term interest rates coefficient of -0.4089 indicates that $1 \%$ decrease in the UK long-term interest rates will culminate in a $0.41 \%$ increase in cross-border capital flows to London CBD office market over the short-run. Pertinently, this also reveals that real estate cross-border capital flows are only responsive to long-term interest rate variation in the short- 
run, implying that poor domestic bond market performance would encourage investment activities in the London office market as foreign investors seek alternative to overpaying for government bonds in the short-run. Surprisingly, the findings for the real effective exchange rate variable, with a coefficient of 7.79 , also shows a positive relationship with international real estate capital flows, indicating that a $1 \%$ appreciation in domestic currency rates will lead to a $7.79 \%$ increase in the level of international capital inflows.

The findings in model (1) reveal that international real estate capital flows are not necessarily driven by inherent office market fundamentals but rather by more external factors including the perception that London offers a safer environment (safe haven) to international investors who had perhaps become more risk adverse in the aftermath of the GFC. However, the analysis does infer the significance of changing investor typology and the risk profile they are willing to accept.

The coefficient of the error correction term (in model (2)) also confirms the results of the bounds test for cointegration, suggesting equilibrium will be attained in the long-run. Further, the coefficient of -0.96 reveals that $96 \%$ of the disequilibrium in the current period will be corrected in the following quarter signalling that the interaction of these explanatory variables in the long-run, through the error correction term, influence the level of cross-border capital flows to the London CBD office market. However, the model (2) findings show that only the global liquidity (LGLDITY) and the UK stock market capitalization coefficients (LUKGDP) indicate significant short-run relationships at the $10 \%$ level (Table V). In line with the reported long-run result, the reported coefficient estimate of the global liquidity (-3.137) implies that a $1 \%$ decrease in global liquidity will lead to around 3.14\% increase in the total cross-border investment flows to the central London office market. Likewise, the estimated coefficient of the UK stock market capitalization variable (3.300) indicates that a $1 \%$ increase in the US stock market capitalization will lead to around $3.30 \%$ increase in the capital flows into London. In this respect, this result suggests that the level of global (ill)liquidity and domestic investors confidence influence the level of capital flows into London office market in the short-run.

The models (1) and (2) short-run causality are estimated using the Wald exogeneity test, where the null hypothesis ${ }^{[5]}$ indicates no short-run causality if all the lagged terms of each independent variable collectively are equal to zero. Model (1) findings (Table VI) show that most of the domestic variables indicate positive and statistically significant short-run causal relationships $(p<.05)$ with the exception of equivalent yield impact and stock market 
capitalization. This suggests that variation in stock market performance only influences the cross-border capital flows in the long-run, thereby supporting the ECM model (1) findings. This also indicates that although the domestic drivers are not necessarily the main factors driving cross-border investment in the office market, they are also important, particularly in the short-run. The findings also infer that perceived long-term confidence in the performance of the London office market is arguably promoted by other factors such as robustness of local laws and institutional frameworks, transparency, resilience and availability of suitable assets.

\section{Table VI}

However, model (2) short-run causality results (Table VI) show a number of pertinent and different findings to model (1). Office market performance variables such as the equivalent yield impact and the total return both show no statistically significant short-run causal relationship. In addition, the other domestic factors variables, the UK GDP and stock market capitalization, also comprise no significant short-run causal relationship with the cross-border capital flows. The findings do however indicate that UK gross rental yield and US stock market capitalization variables indicate a causal relationship in the short-run, albeit at the $10 \%$ level of significance. What is prominent concerns the measurable effects and impacts of currency upon the investment flows. The short-run dynamics reveal the real effective exchange rate variable to display significant short-run causality with international real estate flows at the 5\% level. Moreover, as discussed earlier, world long-run interest rates (bond market performance), global liquidity and Tokyo gross rental yield spread reveal short-run causality with international real estate flows into the London Office market at the 5\% level.

Overall, the examination of internal market conditions and the various (control) factors considered to shape the investment market and reflect the level of cross-border capital investment flows to London CBD office market is more responsive to changes in the domestic environment particularly the office market performance in the short-run than in the long-run. The analysis of the short-run behaviour of cross-border capital flows into London office investment shows that the performance of office market and microeconomic factors are more important in the short-run than in the long-run. Ultimately, there appears to be external dynamics and causes which explain the flows of capital in the London market over the longrun. As a result, model (2) specifically examines the influence of international environment on cross-border capital flows to London CBD office market. The analysis shows that the crossborder investment capital flow to London CBD office market is more responsive to changes in 
the international environment in both the short-run and the long-run than changes in the domestic environment particularly the office market performance.

\section{Discussion}

This paper has analysed the long and short run impacts of both domestic and international factors on cross-border real estate investment in the London CBD office market. In the longrun, the domestic model (model 1) shows that UK stock market capitalization, which indicates the level of domestic investors' confidence, influences cross-border capital flow to the London office market. However, domestic drivers, though important, are not highlighted as the main factor driving international real estate investments in the London office market. Market reality suggests that investors have underlying confidence in the long-run performance of the domestic economy and the office market plausibly due to the level of integration with the global economy, robustness of local laws and institutional frameworks, transparency, resilience and availability of suitable assets.

The international model (model 2) indicates that the level of global liquidity, the exchange rate of the domestic currency, the US stock market capitalization, Tokyo yield spread and the world long-term interest rate as well as the market yield all influence cross-border investment into the London CBD office market. Previous research such as Fostel and Kaminsky (2008) and Gupta et al. (2020) also indicated the influence of global liquidity and exchange rates (respectively) on cross-border capital flows. Furthermore, the linkage with the US financial market has been identified in previous research as the major source of international real estate capital in the London office market globally (McAllister and Nanda, 2016). In terms of the performance of the Tokyo office market and global bond market, the nature of the influence indicated by this study suggest that investors are seemingly showing preference for the London market. The short-run influence of both the domestic and international environment were further evaluated by the short-run causality, the result suggests that there is statistically significant causal influence of both the domestic and international environment on cross border flows to London. This signifies that the influence of the international environment is invigorated by the domestic factors as well as the different risk profile of the diverse investor typology in this office market.

The London office market remains a mecca for international capital flows and in many respects defies conventional real estate investment wisdom and basic market performance fundamentals 
- depicting the multi-faceted and complex 'layers' which underpin the London office market decision making framework. The evidence from our analysis suggest that in periods of global political and economic instability the London office has been a key beneficiary of investor 'risk aversion'. Putting aside the 'trophy' asset sentiment, the London office market remains the most 'liquid' of real estate investment options available to international investors and with bond markets around the world continuing to underperform the perceived 'safety' of London offices remains an attractive proposition. Currency arbitrage undoubtedly plays a key role in the volumes and country of origin of capital flows. Wealth creation within the country of origin (such as within the US stock market for example) ensures that investors are likely to crystallise gains and place capital in assets which afford both diversification and relative stability over the medium to long term. In this respect, and as our analysis suggests, international investors are less concerned about the underlying short run performance of the office sector and more inclined to take advantage of currency arbitrage contented in the knowledge that their investment can be easily liquidated while also accruing capital appreciation over time due to the incessant demand.

The research findings have a series of practical implications for investors seeking both entry into the market, as well as those seeking to pursue an exit strategy. The scale of capital ensures that currency exchange will remain a dominant factor on the entry and exit strategy of investors. Indeed, currency arbitrage alongside the 'safe haven' reputation of the London office sector underpins the global diversity of capital flows and depicts the transposition of global micro and macroeconomics directly into the London office market. London offices will continue to attract swathes of international capital - while the repute of London as an international financial centre was questioned in the wake of Brexit, talk of such demise has been overstated. Indeed in the intervening period, London offices have continued to attract large volumes of international capital as a result of the devaluation of sterling against the Euro and US Dollar ${ }^{5}$. London's reputation as an international financial hub remains intact in spite of some high-profile departures from within the financial services sector in the wake of Brexit. Nonetheless, vacancy rates within the London office sector remain amongst the lowest in Europe and the resilience of occupancy levels even in the midst of the pandemic further consolidates the appeal to the international investment community.

\footnotetext{
${ }^{5}$ Overseas buyers, who accounted for $83 \%$ of activity ( $£ 7.8$ billion) in 2020 (Knight Frank, 2020).
} 
Looking forward, two key themes will significantly influence the investment potential of the office sector. The first, ESG has becoming increasingly well-established over the course of the last five years and as the real estate sector adapts to conform with decarbonisation targets asset quality and the age profile/refurbishment status of real estate assets will assume greater importance. While the magnitude of 'green premiums' may remain contested the threat of 'brown discounts' and premature asset obsolescence are very real. Secondly, the expected increase in home-working post-pandemic is likely to prompt some occupiers to review their office footplates. The need for space, and indeed how occupiers utilise and occupy their space, is likely to evolve but once again the levels of occupier demand coupled with a lack of supply ensure that London offers greater resilience than most other international office markets in the event of occupier rationalisation. Nonetheless, going forward renewed focus will be placed upon location and stock quality ensuring that real estate performance fundamentals are likely to assume greater prominence within the international investor decision making process to reflect the key drivers of demand within the real estate sector and potential changes in working arrangements amongst office employees.

\section{Conclusion}

The London office market has always been a major destination for cross-border capital flows, particularly during periods of global crisis. Considering the pre-eminence of the London office market in the global economy, as a global city and major destination of cross-border capital flows, the holistic study of the influence of both the domestic and international environment provides more insights on the behaviour of global real estate capital flows. In terms of the actual market fundamentals, the analysis reveals the short-run impact of London office market yields on cross-border investment activities. This suggests that in the long-run, international investors are less concerned about market yields but more interested in capital appreciation again illustrating the sentiment towards London being a safe haven for storing wealth and 'trophy assets'. However, taking into consideration the diversity of the nature of investors in this market with different investment objectives, performance seemingly has different impact on the investors' decisions, as investors with short-run and long-run performance motivations interact and dominate the market at different periods (Lizieri and Mekic, 2018).

The influence of the international environment on cross-border capital flows to the London CBD office market highlights the importance of the international drivers. Global factors 
including global liquidity, US stock market capitalization, Tokyo yield spread and performance of the global bond market are all shown as causal variables influencing cross-border office investments into London. Similarly, the analysis indicates the significance of the exchange rates as a major domestic driver of cross-border capital flows. However, the analysis also suggests that, in addition to the influence of the domestic and international environments, the international capital flows into the London office market are driven by other factors which could be attributed to investor perception of the market as a "safe haven" particularly in terms of market liquidity which is also supported by extant studies (Lizieri and Mekic, 2018, Haran et al., 2016, Lizieri and Pain, 2013).

Overall, this paper highlights the critical differences in the influence of the domestic and global environment on cross-border real estate capital flow into the London office market. The significance of these differences cannot be over-stated as international investors seek to understand the potential impact of the increasing global uncertainty on cross-border real estate investment activities. This has the potential to create further research opportunity by applying similar methodological framework to net cross-border activity or domestic activity in the London office market. Furthermore, the empirical analysis could also be extended to other global cities to decipher the influence of international relative to domestic drivers in other markets.

\section{Endnotes}

1. Real Capital Analytics (RCA) is an independent property research organisation, which provides the largest, most comprehensive and extensively used international commercial property capital flows database by major institutional investors and the research community. There are some limitations with the RCA database; firstly, the database does not include transactions involving deals less than $\$ 10$ million. Secondly, as highlighted by McAllister and Nanda (2015 and 2016), there are issues with the treatment of investment nationality particularly concerning the definition of crossborder investments and the conceptual problem associated with the notion of 'foreignness' of investments.

2. Based on rejection of the Null hypothesis

3. Cointeq $=$ LLONFLOW $-(0.0189$ EQUIVYIELD_IMPACT 0.0220GRRYIELDLON -0.3847LUKGDP + 1.4738LUKMCAP + 1.9569LUKREER +0.0036 TOTAL_RETURN_DES -0.0818UK_LTIR - 24.375)

4. The results of the various stability checks show no presence of serial correlation $(p>0.05)$ or heteroscedasticity ( $p>0.05)$, with the Jarque-Bera statistic and $p$-value also indicating no statistical significance and acceptance of the null hypothesis that the residuals are normally distributed. The CUSUM and CUSUM plot of square tests results (Figure 1) are within the critical bands of the 5\% confidence interval of 
parameter stability, thereby indicating the stability of the coefficients. The Ramsey RESET tests also confirm the model to be correctly specified ( $>>0.05)$ (Appendix 2).

5. for example $(\mathrm{c}(2)=\mathrm{c}(3)=\mathrm{c}(4)=0$

6. Based on equation: Cointeq $=$ LLONFLOW - (0.0488 EQUIVYIELD_IMPACT + 0.8155 GRRYIELDLON -4.9633LGLDITY -0.0636LJPMKTCAP + 3.6687LUKGDP -4.3733LUKREER + 1.7532LUSMKTCAP + 0.0476LVIX + 0.1526NYSPREAD 0.5464LUKMCAP -1.1812TOKSPREAD + 0.0418TOTAL_RETURN_DES 0.3457 WLTIR + 30.9613)

\section{References}

Alfaro, L., Kalemli-Ozcan, S. and Volosovych, V. (2007), "Capital flows in a globalized world: The role of policies and institutions", in Edwards, S. (Ed.). Capital controls and capital flows in emerging economies: Policies, practices and consequences. University of Chicago Press, pp.19-72. https://doi.org/10.7208/chicago/9780226184999.003.0002

Barkham, R.J., and Schoenmaker, D.A.J. (2017), "How much real estate? A global city analysis. CBRE ViewPoint: Global Investment", available at: http://cbre.vo.llnwd.net/grgservices/secure/ViewPoint\%20\%20How\%20Much\%20Real\%20Estate.pdf?e=1549806132\&h=834344d31eebb50b5 $660952 \mathrm{f03f7cd03}$ (accessed 2 September 2017)

Beirne, J., Renzhi, N., Sugandi, E., and Volz, U. (2021), "COVID-19, asset markets and capital flows". Pacific Economic Review. https://doi.org/10.1111/1468-0106.12368

Bluedorn, J., Duttagupta, R., Guajardo, J. and Topalova, P. (2013), "Capital Flows are Fickle: Anytime, Anywhere”, working Paper [13/183], International Monetary Fund.

Brown, G.R. and Matysiak, G. A. (2000), Real estate investment: a capital market approach, Financial Times Prentice Hall.

Burrell (2015), Emerging International Real Estate Markets. IPF Research Programme Short Paper Series.

Chin, W., Dent, P. and Roberts, C. (2006), "An exploratory analysis of barriers to investment and market maturity in southeast Asian cities", Journal of Real Estate Portfolio Management, Vol. 12 No. 1, pp. 49-57. https://doi.org/10.1080/10835547.2006.12089738

Corsetti, G., and Marin, E. (2020), "The dollar and international capital flows in the COVID19 crisis". VOX CEPR Policy Portal, available at: https://voxeu.org/article/covid-19crisis-dollar-and-capital-flows (accessed 22 September 2021)

Darku, A.B. (2019), "Exports, capital inflows, relative prices, and income growth in South Korea: An application of the balance of payments constraint growth model", International Journal of Finance and Economics, Vol. 24, pp. 288- 295. https://doi.org/10.1002/ijfe.1662

Devaney, S., McAllister, P. and Nanda, A. (2017a) "Determinants of transaction activity in commercial real estate markets: evidence from European and Asia-Pacific countries", Journal of Property Research, Vol. 34 No. 4, pp.251-268. https://doi.org/10.1080/09599916.2017.1383931

Devaney, S., McAllister, P. and Nanda, A. (2017b), "Which factors determine transaction activity across U.S. metropolitan office markets?", The Journal of Portfolio Management, Vol. 43 No.6, pp. 90-104. https://doi.org/10.3905/jpm.2017.43.6.090 
Dickey, D., \& Fuller, W. (1979), "Distribution of the estimators for autoregressive time series with a unit root", Journal of the American Statistical Association, Vol. 74 No. 366, pp. 427-431. https://doi.org/10.2307/2286348

Fadeyi, O. (2019), "Capital Flow and Real Estate Office Markets in Global Financial Cities", Thesis [Unpublished doctoral dissertation]. University of Ulster.

Fadeyi, O., McGreal, S., McCord, M. and Berry, J. (2020), "Capital flows and office markets in major global cities", Journal of Property Investment \& Finance. https://doi.org/10.1108/JPIF-02-2020-0023

Forbes, K. J. and Warnock, F. E. (2012), "Capital flow waves: surges, stops, flight, and retrenchment", Journal of International Economics, Vol 88 No. 2, pp. 235-251. https://doi.org/10.3386/w17351

Fostel, A. and Kaminsky, G. L. (2008), "Latin America's access to international capital markets: good behaviour or global liquidity?", in: Cowan, K. [Ed.]. Central banking, analysis, and economic policies book series current account and external financing. 1st ed. Central Bank of Chile, pp. 117-158. https://repositoriodigital.bcentral.cl/xmlui/handle/20.500.12580/3734

Fuerst, F. and Grandy, A. (2012), Rational expectations?: Developer behaviour and development cycles in the central London office market. Journal of Property Investment \& Finance, 30(2), 159-174. https://doi.org/10.1108/14635781211206904

Fuerst, F., Lim, W. and Matysiak, G. (2013), "Drivers of Fund Performance", INREV, Amsterdam.

Fuerst, F., Milcheva, S. and Baum, A. (2015), "Cross-border capital flows into real estate", Real Estate Finance, Vol. 31 No. 3, pp. 103-122. https://dx.doi.org/10.2139/ssrn.2352073

Gupta, A., Newell, G., Bajaj, D. and Mandal, S. (2020), "Determinants of foreign and domestic non-listed real estate fund flows in India", Journal of Property Investment \& Finance. https://doi.org/10.1108/JPIF-08-2019-0107

Greater London Authority (2017) “London Office Policy Review 2017”, a report by Ramidus Consulting Limited In association with CAG Consulting, available at: https://www.london.gov.uk/sites/default/files/london_office_policy_review_2017_fin al_17_06_07.pdf (accessed 12 December 2017)

Haran, M., McCord, M., Davis, P., McCord, J., Lauder, C. and Newell, G. (2016). European emerging real estate markets: Re-examining investment attributes and framing opportunities. Journal of Property Investment \& Finance, 34(1), 27-50. https://doi.org/10.1108/JPIF-04-2015-0024

Harris, R. and Sollis, R. (2003), Applied time series modelling and forecasting. John Wiley and Sons.

Hoesli, M., Lekander, J. and Witkiewicz, W. (2004), "International Evidence on Real Estate as a Portfolio Diversifier", Journal of Real Estate Research, Vol. 26, pp.161206.

Johansen, S. (1991) "Estimation and hypothesis testing of cointegration vectors in Gaussian vector autoregressive models", Econometrica, Vol. 59 No. 6, pp.1551-1580. https://doi.org/10.2307/2938278

Knight Frank (2020) Themes shaping London's office market. Available online at: https://www.knightfrank.com/london-report/2021-02-03-what-next-for-londonscommercial-investment-market. Last Accessed: Sept 2021.

Lee, H.K (2013), “A cointegration analysis of inflation and real estate returns”, Journal of Real Estate Portfolio Management, Vol. 19 No. 3, pp.207-224. https://doi.org/10.1080/10835547.2013.12089956 
Lee, K.N.H. (2017), "Residential property price-stock price nexus in Hong Kong: new evidence from ARDL bounds test", International Journal of Housing Markets and Analysis, Vol. 10 No. 2, pp. 204-220. https://doi.org/10.1108/IJHMA-03-2016-0020

Li, J. and Chen, X. (2015), "Analysis of China's real estate prices and macroeconomy based on evolutionary co-spectral method", Journal of Industrial Engineering and Management, Vol. 8 No. 2, pp. 598-614.

Lieser, K. and Groh, A.P. (2014), "The determinants of international commercial real estate investment", The Journal of Real Estate Finance and Economics, Vol. 48 No. 4, pp. 611-659. https://doi.org/10.1007/s11146-012-9401-0

Liow, K.H., Ibrahim, M.F. and Huang, Q. (2006), "Macroeconomic risk influences on the property stock market", Journal of Property Investment and Finance, Vol. 24 No. 4, pp. 295-323.

Liow, K.H. (2014), "The dynamics of return co-movements and volatility spillover effects in China public property markets and international linkages", Journal of Property Investment and Finance, Vol. 32 No. 6, pp. 610-641. https://doi.org/10.1108/JPIF-062014-0039

Liow, K.H. and Schindler, F. (2017), "Linkages between office markets in Europe: a volatility spillover perspective", Journal of Property Investment and Finance, Vol. 35 No. 1, pp. 3-25. https://doi.org/10.1108/JPIF-02-2016-0010

Lizieri, C. and Mekic, D. (2018), "Real estate and global networks: drilling into the city of London", in Hoyler, M., Parnreiter, C. and Watson, A. [Ed.s], Global City Makers. Edward Elgar

Lizieri, C. and Pain, K. (2014), "International office investment in global cities: the production of financial space and systemic risk", Regional Studies, Vol. 48 No. 3, pp. 439-455. https://doi.org/10.1080/00343404.2012.753434

McAllister, P., and Nanda, A. (2015), "Does foreign investment affect US office real estate prices?”. The Journal of Portfolio Management, Vol. 41, pp. 38-47. doi:10.3905/jpm.2015.41.6.038

McAllister, P. and Nanda, A. (2016), "Does real estate defy gravity? An analysis of foreign real estate investment flows", Review of International Economics, Vol. 24 No. 5, pp. 924-948. https://doi.org/10.1111/roie.12228

McGreal, S., Parsa, A. and Keivani, R. (2001), "Perceptions of real estate markets in Central Europe: a survey of European investors", Journal of Real Estate Literature, Vol. 9 No. 2, pp. 147-160. https://doi.org/10.2307/44103422

Newell, G. and Lee, C.L. (2017), "The Impact of Currency on the Performance of European Non-listed Real Estate Funds", INREV, Amsterdam.

Nickol, P., and Stoppok, L. (2020), "The collapse of capital flows to emerging markets: What are the consequences". The World Economy after the Coronavirus Shock: Restarting Globalization, pp. 41-48, available at: https://www.ifwkiel.de/fileadmin/Dateiverwaltung/IfW-Publications/-

ifw/Kieler_Beitraege zur_Wirtschaftspolitik/2020/wipo_26.pdf (accessed 22 September 2021).

Ozge Akinci, O., Benigno, G. and Queraltó, A. (2020), "Modeling the Global Effects of the COVID-19 Sudden Stop in Capital Flows," FEDS Notes 2020-07-02, Board of Governors of the Federal Reserve System (U.S.), available at: (accessed 22 September 2021).

Akinci, O., Benigno,G. and Queralto, A. (2020). "Modeling the Global Effects of the COVID19 Sudden Stop in Capital Flows," FEDS Notes. Washington: Board of Governors of the Federal Reserve System, July 02, 2020, https://doi.org/10.17016/2380-7172.2586. 
Pesaran, M.H., Shin, Y. and Smith, R.J. (2001), "Bounds testing approaches to the analysis of level relationships", Journal of Applied Econometrics, Vol. 16 No. 3, pp. 289-326. https://doi.org/10.1002/jae.616

Pi-Ying Lai, P. and Fischer, D. (2007), "The determinants of foreign real estate investment in Taiwan”, Pacific Rim Property Research Journal, Vol. 13 No. 3, pp. 263-279. https://doi.org/10.1080/14445921.2007.11104233

Poon, J. (2017), "Foreign direct investment in the UK real estate market", Pacific Rim Property Research Journal, Vol. 23 No. 3, pp. 249-266. https://doi.org/10.1080/14445921.2017.1372038

Rapach D.E, Strauss J.K. (2007), "Forecasting real housing price growth in the eighth district states", Federal Reserve Bank of St Louis: Regional Economic Development, Vol. 3 No. 2, pp. 33-42.

Rapach DE, Strauss JK. (2009), "Differences in housing price forecast ability across U.S. states", International Journal of Forecasting, Vol. 25 No. 2, pp. 351-372. https://doi.org/10.1016/j.ijforecast.2009.01.009

Reinhart, C. and Reinhart.V. (2009), "Capital flow bonanzas: an encompassing view of the past and present", NBER International Seminar on Macroeconomic, Vol. 5 No. 1, pp. 9-62. https://doi.org/10.1086/595995

RCA (2021), "These were the largest property markets worldwide in 2020", available at: https://www.rcanalytics.com/largest-global-markets-2020/ (accessed 10 March 2021)

Salem, M. and Baum, A. (2016), "Determinants of foreign direct real estate investment in selected MENA countries", Journal of Property Investment and Finance, Vol. 34 No. 2, pp. 116-142. https://doi.org/10.1108/JPIF-06-2015-0042

Sarno, L., Tsiakas, I. and Ulloa, B. (2016), "What drives international portfolio flows?", Journal of International Money and Finance, Vol. 60, pp. 53-72. https://doi.org/10.1016/j.jimonfin.2015.03.006

Shirota, T. (2015), "What is the major determinant of cross-border banking flows?", Journal of International Money and Finance, Vol. 53, pp. 137- 147. https://doi.org/10.1016/j.jimonfin.2015.01.001

Shrestha, M. B. and Bhatta, G. R. (2018), "Selecting appropriate methodological framework for time series data analysis", The Journal of Finance and Data Science, Vol. 4 No. 2, pp. 71-89. https://doi.org/10.1016/j.jfds.2017.11.001

Srivatsa, R. and Lee, S. L. (2012), "European real estate market convergence", Journal of Property Investment \& Finance, Vol. 30 No. 5, pp. 458-472. https://doi.org/10.1108/14635781211256738

Stevenson, S., Akimov, A., Hutson, E. and Krystalogianni, A. (2014), "Concordance in global office market cycles”, Regional Studies, Vol. 48 No. 3, pp. 456-470. https://doi.org/10.1080/00343404.2013.799763

Worthington, A. and Higgs, H. (2013), "Macro drivers of Australian housing affordability, 1985-2010: an autoregressive distributed lag approach". Studies in Economics and Finance, Vol. 30 No. 4, pp. 347-369. https://doi.org/10.1108/SEF-07-2012-0078

Zhu, B and Lizieri, C. (2020), "Connected markets through global real estate investments", Real Estate Economics, pp. 1-37. https://doi.org/10.1111/1540-6229.12319

Zhu, B. and Lizieri, C. (2018). "Connected markets through global real estate investments", in Real Estate Research Institute Conference, 9-10 May 2018, Chicago, USA. 


\section{Appendices}

Appendix 1. Summary Statistics

\begin{tabular}{|c|c|c|c|c|c|}
\hline Variable & Observation & Mean & Std Dev & Maximum & Minimum \\
\hline \multicolumn{6}{|l|}{ Domestic } \\
\hline $\begin{array}{l}\text { Total gross cross border } \\
\text { capital Inflows (in Billions) }\end{array}$ & 44 & 4.16774 & 2.05149 & 10.94416 & 0.86516 \\
\hline Long term interest rates & 43 & 2.607302 & 1.255027 & 5.266000 & 0.721000 \\
\hline $\begin{array}{l}\text { Log of real effective } \\
\text { exchange rates }\end{array}$ & 43 & 4.660724 & 0.073535 & 4.842044 & 4.551058 \\
\hline $\begin{array}{l}\text { De-smoothed Total } \\
\text { returns }\end{array}$ & 43 & 1.754411 & 6.108305 & 15.35462 & -20.63653 \\
\hline Log of UK GDP & 43 & 13.43207 & 0.089810 & 13.60115 & 13.22698 \\
\hline $\begin{array}{l}\text { Log of stock market } \\
\text { capitalization }\end{array}$ & 43 & 14.94064 & 0.179976 & 15.20221 & 14.32123 \\
\hline Equivalent yield impact & 43 & 0.105452 & 3.704503 & 9.533220 & -11.16557 \\
\hline Gross Rental yield & 43 & 4.996828 & 1.171518 & 7.878360 & 3.682720 \\
\hline International & 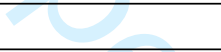 & & & & \\
\hline Log of VIX index & 43 & 2.924859 & 0.371923 & 3.787366 & 2.252344 \\
\hline Log of global liquidity & 43 & 16.60853 & 0.138627 & 16.84290 & 16.28253 \\
\hline $\begin{array}{l}\text { World Long term interest } \\
\text { rates }\end{array}$ & 43 & 2.318204 & 0.936848 & 4.060884 & 0.736108 \\
\hline $\begin{array}{l}\text { Log of US stock market } \\
\text { capitalization }\end{array}$ & 43 & 16.53414 & 0.243979 & 16.91024 & 15.88814 \\
\hline $\begin{array}{l}\text { Log of Japan stock market } \\
\text { capitalization }\end{array}$ & 43 & 15.21957 & 0.189613 & 15.64105 & 14.77667 \\
\hline $\begin{array}{l}\text { Tokyo gross rental yield } \\
\text { spread }\end{array}$ & 43 & -0.669832 & 1.000771 & 2.056840 & -1.715003 \\
\hline $\begin{array}{l}\text { New York gross rental } \\
\text { yield spread }\end{array}$ & 43 & -2.036064 & 0.535785 & -0.502420 & -2.796070 \\
\hline
\end{tabular}

Appendix 2.

\begin{tabular}{llllll}
\hline & \multicolumn{2}{l}{ Breusch-Godfrey } & Breusch-Pagan- Ramsey & Jarque-Bera & CUSUM and \\
& Serial & CUSUM of square \\
& Correlation LM & Godfrey & RESET & & Available on request \\
\hline Table 5 & 0.0992 & 0.783 & 0.4841 & 0.2833 & Available on request \\
Table 6 & 0.2020 & 1.9044 & 0.5594 & 0.4719 & Available on request \\
Table 9 & 1.1522 & 0.9448 & 1.0409 & 0.3978 & Available on request \\
Table 10 & 0.3877 & 0.6377 & 0.9819 & 0.7965 & \\
\hline
\end{tabular}




\section{Tables}

\section{Table I Summary of variables drawn from the literature}

\begin{tabular}{ll}
\hline Parameter & Previous Research \\
\hline Long term interest rates & $\begin{array}{l}\text { Fuerst et al. (2013), Li and Chen (2015), Poon (2017), Zhu } \\
\text { and Lizieri (2020), Gupta et al. (2020) }\end{array}$ \\
Exchange rate & Liow et al. (2006), Hoesli et al. (2004), Newell and Lee \\
& (2017), Zhu and Lizieri (2020), Gupta et al. (2020) \\
Property market performance & Fuerst et al. (2015), Zhu and Lizieri (2020) \\
Size of national economy & Poon (2017), Zhu and Lizieri (2020), Gupta et al. (2020) \\
Stock market & Fuerst et al. (2013), Zhu and Lizieri (2020), Gupta et al. \\
VIX index & $(2020)$ \\
Money supply & Zhu and Lizieri (2020), \\
& Liow et al. (2006), Li and Chen (2015), Gupta et al. (2020) \\
\hline
\end{tabular}

Table II. Domestic and international performance measures

\begin{tabular}{|c|c|c|c|c|}
\hline Variable & Description & Source & Variable Code & $\begin{array}{l}\text { Expected } \\
\text { sign }\end{array}$ \\
\hline \multicolumn{5}{|l|}{ Domestic } \\
\hline $\begin{array}{l}\text { Total cross border capital } \\
\text { Inflows }\end{array}$ & $\begin{array}{l}\text { The volume of } \\
\text { international real estate } \\
\text { investment (Gross } \\
\text { capital flows) }\end{array}$ & & LONFLOW & \\
\hline Long term interest rates & $\begin{array}{l}\text { Long-term interest } \\
\text { rates to measure the } \\
\text { domestic bond market } \\
\text { performance }\end{array}$ & OECD & UKLTIR & - \\
\hline $\begin{array}{l}\text { Log of real effective } \\
\text { exchange rates }\end{array}$ & $\begin{array}{l}\text { Reflects the } \\
\text { performance of the } \\
\text { domestic currency }\end{array}$ & IMF & LUKREER & - \\
\hline De-smoothed Total returns & $\begin{array}{l}\text { Measure of returns } \\
\text { performance in the } \\
\text { office market }\end{array}$ & MSCI & $\begin{array}{l}\text { TOTAL } \\
\text { RETURN DES }\end{array}$ & + \\
\hline Log of UK GDP & $\begin{array}{l}\text { Measure of domestic } \\
\text { growth }\end{array}$ & IMF & LUKGDP & + \\
\hline $\begin{array}{l}\text { Log of stock market } \\
\text { capitalization }\end{array}$ & $\begin{array}{l}\text { Measure of domestic } \\
\text { stock market } \\
\text { performance }\end{array}$ & $\begin{array}{l}\text { World } \\
\text { Bank }\end{array}$ & LUKMCAP & \\
\hline Equivalent yield impact & $\begin{array}{l}\text { Captures the } \\
\text { performance of the } \\
\text { domestic office market }\end{array}$ & MSCI & $\begin{array}{l}\text { EQUIVYIELD } \\
\text { IMPACT }\end{array}$ & \\
\hline Gross Rental yield & $\begin{array}{l}\text { Captures the } \\
\text { performance of the }\end{array}$ & MSCI & GRRYIELDLON & + \\
\hline
\end{tabular}




\begin{tabular}{|c|c|c|c|c|}
\hline & \multicolumn{4}{|l|}{ domestic office market } \\
\hline \multicolumn{5}{|l|}{ International } \\
\hline Log of VIX index & Measure of global risk & $\mathrm{CBOE}$ & LVIX & - \\
\hline Log of global liquidity & $\begin{array}{l}\text { Measure of global } \\
\text { money supply }\end{array}$ & IMF & LGLDITY & + \\
\hline $\begin{array}{l}\text { World Long term interest } \\
\text { rates }\end{array}$ & $\begin{array}{l}\text { Measure of global bond } \\
\text { market performance }\end{array}$ & OECD & WLTIR & - \\
\hline $\begin{array}{l}\text { Log of US stock market } \\
\text { capitalization }\end{array}$ & $\begin{array}{l}\text { Measure of the US } \\
\text { stock market } \\
\text { performance }\end{array}$ & $\begin{array}{l}\text { World } \\
\text { Bank }\end{array}$ & LUSMKTCAP & + \\
\hline $\begin{array}{l}\text { Log of Japan stock market } \\
\text { capitalization }\end{array}$ & $\begin{array}{l}\text { Measure of Japan stock } \\
\text { market performance } \\
\text { The difference between }\end{array}$ & $\begin{array}{l}\text { World } \\
\text { Bank }\end{array}$ & LUSMKTCAP & - \\
\hline $\begin{array}{l}\text { Tokyo gross rental yield } \\
\text { spread }\end{array}$ & $\begin{array}{l}\text { London and Tokyo } \\
\text { office market } \\
\text { performance }\end{array}$ & MSCI & TOKSPREAD & - \\
\hline $\begin{array}{l}\text { New York gross rental } \\
\text { yield spread }\end{array}$ & $\begin{array}{l}\text { The difference between } \\
\text { London and New York } \\
\text { office market } \\
\text { performance }\end{array}$ & MSCI & NYSPREAD & - \\
\hline
\end{tabular}

Table III: Augmented Dickey-Fuller unit root test

\begin{tabular}{llll}
\hline Variable & t-statistic & Critical value & Order of Integration \\
\hline LLONFLOW & $-5.0812 * * *$ & -2.9369 & $\mathrm{I}(1)$ \\
UKLTIR & $-6.522 * * *$ & -2.935 & $\mathrm{I}(1)$ \\
LUKREER & $-3.079 * *$ & -2.9411 & $\mathrm{I}(0)$ \\
TOTAL & $-5.5702 * * *$ & -2.9484 & $\mathrm{I}(0)$ \\
RETURN DES & $-3.1017 * *$ & -2.939 & $\mathrm{I}(1)$ \\
LUKGDP & $-4.4027 * * *$ & -2.9369 & $\mathrm{I}(1)$ \\
LUKMCAP & -2.9458 & $\mathrm{I}(0)$ \\
EQUIVYIELD & $-8.9053 * * *$ & -2.9511 & $\mathrm{I}(1)$ \\
IMPACT & $-4.0936 * * *$ & -2.9434 & $\mathrm{I}(1)$ \\
GRRYIELDLON & $-3.7073 * * *$ & $\mathrm{I}(1)$ \\
LVIX & $-5.3614 * * *$ & -2.9389 & $\mathrm{I}(1)$ \\
LGLDITY & $-6.5220 * * *$ & -2.935 & $\mathrm{I}(1)$ \\
WLTIR & $-6.6619 * * *$ & -2.9484 & $\mathrm{I}(1)$ \\
LUSMKTCAP & -2.939 & $\mathrm{I}(0)$ \\
LUSMKTCAP & $-3.1565 * *$ & -2.9484 & $\mathrm{I}(0)$ \\
TOKSPREAD & $-3.7013 * * *$ & -2.939 & $\mathrm{~N}$ \\
NYSPREAD & $-4.0041 * * *$ & . & \\
\hline
\end{tabular}

$* * *$ denotes $1 \%$ significance; $* * 5 \%$ significance. Critical value at $5 \%$ level. NB: No intercept or trend. Results based quarterly data for 2007-2017. 
Table IV: ARDL bounds test and long-run models

\begin{tabular}{lllll}
\hline \multirow{2}{*}{ Variable } & \multicolumn{3}{c}{ Model (1) } & Model (2) \\
\cline { 2 - 5 } & Coefficient & t-Statistic & Coefficient & t-Statistic \\
\hline EQUIVYIELD IMPACT & 0.0189 & 0.5088 & 0.0488 & 0.7834 \\
GRRYIELDLON & -0.022 & -0.21669 & 0.8155 & $1.7123^{*}$ \\
LUKGDP & -0.3847 & -0.2748 & 3.6687 & 1.6825 \\
LUKMCAP & 1.4738 & $2.33621^{* *}$ & -0.5464 & -0.4195 \\
LUKREER & 1.9569 & 1.5564 & -4.3733 & $-2.0730^{* *}$ \\
TOTAL RETURN DES & 0.0036 & 0.1618 & 0.0418 & 1.0484 \\
UKLTIR & -0.0818 & -1.0832 & & \\
LGLDITY & & & -4.9633 & $-3.4941^{* * *}$ \\
LJPMKTCAP & & & -0.0636 & -0.0659 \\
LUSMKTCAP & & & 1.7532 & $2.1532^{* *}$ \\
LVIX & & & 0.0476 & 0.1508 \\
NYSPREAD & & & 0.1526 & 0.8261 \\
TOKSPREAD & & & -1.1812 & $-2.3002^{* *}$ \\
TOTAL_RETURN_DES & & & 0.0418 & 1.0484 \\
WLTIR & & $-1.9002^{*}$ & -0.3457 & $-2.3822^{* *}$ \\
Intercept & -24.375 & & 6.9613 & 1.3323 \\
\hline F-stat & 7.5617 & & 1.98 & \\
L. bound I(0) & 2.17 & & 3.04 & \\
U. bound I(1) & 3.21 & & & \\
\hline
\end{tabular}

**denotes $5 \%$ significance; $* 10 \%$ significance. Dependent variable: $\log$ of LONFLOW(LLONFLOW). NB: AIC used to select the best model selection. All the lower bound and upper bound critical values are obtained from Eviews based on Table CI (iii) Case II: restricted intercept and no trend (Pesaran et al., 2001).

Table V: Error correction models

\begin{tabular}{lccll}
\hline \multirow{2}{*}{ Variable } & \multicolumn{2}{c}{ Model (1) } & \multicolumn{2}{c}{ Model (2) } \\
\cline { 2 - 5 } C & Coefficient & t-Statistic & Coefficient & t-Statistic \\
D(LLONFLOW(-1)) & 0.000522 & 0.008871 & 0.0177 & 0.2502 \\
D(UK_LTIR(-1)) & -0.322809 & $-2.264904^{* *}$ & -0.2916 & $-1.9141^{*}$ \\
D(LUKGDP(-1)) & -0.408914 & $-2.432255^{* *}$ & & \\
D(TOTAL_RETURN_DES(-1)) & -1.694728 & -0.868138 & -2.0092 & -0.6657 \\
D(GRRYIELDLON(-1)) & 0.032423 & 1.473024 & 0.0192 & 0.8068 \\
D(EQUIVYIELD_IMPACT(-1)) & 0.024219 & 0.107719 & -0.004 & -0.0041 \\
D(LUKREER(-1)) & -0.024514 & -0.474013 & 0.0111 & 0.1835 \\
D(LUKMCAP(-1)) & 7.799586 & $3.31092^{* * *}$ & 2.4483 & 0.8895 \\
D(LGLDITY(-1)) & 1.096942 & 1.35781 & 3.3001 & $1.7453^{*}$ \\
D(LJPMKTCAP(-1)) & & & -3.1371 & $-1.8192^{*}$ \\
D(LUSMKTCAP(-1)) & & & -2.1278 & -1.6842 \\
D(LVIX(-1)) & & & 1.3542 & 0.9033 \\
D(NYSPREAD(-1)) & & & 0.494 & 1.4493 \\
D(TOKSPREAD(-1)) & & & 0.1027 & 0.3776 \\
D(WLTIR(-1)) & & & -0.5795 & -1.7023 \\
& & & & 0.0907
\end{tabular}


Table VI: Wald Exogeneity test results

\begin{tabular}{lll}
\hline & Model $(1)$ & Model $(2)$ \\
\cline { 2 - 3 } Variable & F-Statistic & F-Statistic \\
\hline EQUIVYIELD_IMPACT & 2.9100 & 0.6219 \\
GRRYIELDLON & $3.5384^{* *}$ & $3.036^{*}$ \\
LUKGDP & $2.7858^{*}$ & 2.5603 \\
LUKMCAP & 1.2992 & 0.1722 \\
LUKREER & $4.3162^{* *}$ & $4.3713^{* *}$ \\
TOTAL RETURN DES & $5.4926^{* * *}$ & 0.6989 \\
UK LTIR & $3.3444^{* *}$ & \\
LGLDITY & & $6.1717^{* * *}$ \\
LJPMKTCAP & & 0.0043 \\
LUSMKTCAP & & $3.0557^{*}$ \\
LVIX & & 1.6078 \\
NYSPREAD & & 0.7404 \\
TOKSPREAD & $6.0292^{* * *}$ \\
WLTIR & & $5.863 * *$ \\
\hline \multicolumn{2}{c}{$* *$ denotes $1 \%$ significance; $* * 5 \%$ significance; $* 10 \%$ significance } &
\end{tabular}
NB: $* * *$ denote $1 \%$ significance; $* * 5 \% ; * 10 \%$. The optimal lag for the model is selected using the Akaike information criterion. The equation ( 5 and 7$)$ is estimated by OLS regression using one lag. The result of the short-run dynamic coefficients associated with the long run relationship obtained from the equation ${ }^{[6]}$ is presented in Table IX $^{[4]}$.

\begin{tabular}{|c|c|c|c|c|}
\hline $\operatorname{ECT}(-1)$ & -0.950878 & $-4.162773 * * *$ & -0.9636 & $3.5544 *$ \\
\hline R-squared & 0.663984 & & 0.7128 & \\
\hline Adjusted R-squared & 0.56643 & & 0.5404 & \\
\hline F-statistic & $6.806377 * * *$ & & $4.136 * * *$ & \\
\hline
\end{tabular}
denotes $1 \%$ significance; $* * 5 \%$ significance; $* 10 \%$ significance $^{[4]}$ 